\title{
PROCEDURES FOR DISABILITY ISSUES IN THE EDUCATION OF EDUCATION IN HIGHER EDUCATION
}

\author{
Dheka Dwi Agustiningsih ${ }^{1}$ dan Erik Rusmana ${ }^{2}$ \\ ${ }^{1}$ Program Studi Manajemen Universitas Islam Bandung, Jl. Tamansari No. 1 Bandung \\ ${ }^{2}$ Program Studi Sastra Inggris, Jl. Setiabudi No. 193 Bandung \\ Surel: ${ }^{1}$ ddagusti@unisba.ac.id; ${ }^{2}$ erik.rusmana@unpas.ac.id \\ DOI: $10.29313 /$ tjpi.v6i1.2329 \\ Accepted: April 5th, 2017. Approved: June 28th, 2017. Published: July 20th, 2017
}

\begin{abstract}
This paper discusses the issue of disability in universities that aims to discuss universities that must play a role and participate in the government and society to build and improve the lives of people with disabilities through the activities of Tridharma. The method used in this analysis is descriptive. The legal basis for persons with disabilities to obtain the right to education is the 1945 Constitution Article 31 paragraph 1 with the implementation of the paradigm of inclusive education in higher education reviewed by the Minister of Education and Culture No. 26 of 2014. In Islam, disability is implied in the letter of At-tin verse 4 and Al-Hujurat verse 13. Understanding disability-friendly education is one of the obligations that must be implemented about human beings and with the constitution through: (1) The equivalent to register; (2) freedom of choice of study program/department; (3) providing services as needed.
\end{abstract}

Keywords: Disabilities', Streaming, dan Higher Educational.

\section{ABSTRAK}

Tulisan ini membahas isu disabilitas di perguruan tinggi yang bertujuan untuk membahas tentang perguruan tinggi yang harus berperan dan berpartisipasi bersama pemerintah dan masyarakat untuk membangun dan meningkatkan taraf hidup penyandang disabilitas melalui kegiatan Tridharma. Metode yang digunakan dalam analisis ini adalah deskriptif. Adapun landasan hukum bagi penyandang disabilitas mendapatkan hak pendidikan adalah UUD 1945 Pasal 31 ayat 1 dengan implementasi paradigma pendidikan inklusif di pendidikan tinggi yang diulas sesuai dengan peraturan Menteri Pendidikan dan Kebudayaan Nomor 26 Tabun 2014. Dalam Islam disabilitas di antaranya disiratkean dalam surat At-tin ayat 4 surat Al-Hujurat dan ayat 13. Memahami pendidikan yang ramah terhadap penyandang disabilitas merupakan salah satu kewajiban yang harus dilaksanakan dalam rangka hubungan dengan manusia dan dengan konstitusi melalui: (1) pemberian kesempatan yang setara untuk mendaftar; (2) kebebasan memilih program studi/jurusan; (3) pemberian layanan sesuai dengan kebutuhan.

Kata Kunci: Disabilitas, Pengarusutamaan, dan Perguruan Tinggi. 


\section{INTRODUCTION}

Each educational institution has noble ideals and has an obligation to participate in educating the nation. Similarly, with universities, especially Islamic colleges who have the desire and goal to realize the education that produces a devoted man to Allah SWT, knowledgeable, noble morals.

Universities as educational institutions have an obligation to participate in the intellectual life of the nation as one of the goals of the state as mentioned in the Preamble of the 1945 Constitution of the fourth paragraph. Education must be accessible to all levels of society so that the goal can be achieved because through education the progress of national development can be achieved.

As an institution that is closely related to the livelihood of the people, with the best dreams for the future of society, universities should not be "ivory towers." Universities and communities are institutions that must work together to empower themselves in efforts to educate the nation and achieve common prosperity. Colleges and communities have a reciprocal relationship that can not be separated from one another. Universities are one institution that facilitates the community to be smart. Instead, society is the input and output of the college itself.

One group of people who should have equal opportunities in different lives are people with disabilities. Law No. 4. of 1997 Article 9 which provides for the protection of persons with disabilities affirms that each person with disabilities has equal opportunity in all aspects of life and livelihood.

Earlier the term of PwDs (people with disabilities) was known as disabled/invalid. The term disabled is new in Indonesia, but in the international context more people with disabilities are more used (Ro'fah and Muhrisun, 2010: 12). Broadly speaking, the types of disabilities consist of physical disability, mental disability, and dual disability. Physical disabilities include not seeing (blind), unable to hear and or less in hearing (deaf), unable to speak (mute), disability, sound and tone defects. Meanwhile, mental disability is difficult to control emotionally and socially, mindflawed, and lacking in power (Ningsih 2014: 78).

Indonesia is one of the countries that have ratified the UN Convention on the Rights of Persons with Disabilities, namely the Convention on the Rights of Persons with Disabilities and make it into Law No. 19 of 2011. Therefore, inclusive education for persons with disabilities must be implemented in Indonesia.

Law no. 19 of 2011 stipulates that each country is required to realize the rights contained in the Convention by adjusting the laws, regulations, and administration of each country including amending discriminatory laws, rules and practices against persons with disabilities, women and children, ensuring participation Persons with disabilities in all aspects of life and education, work, politics, sports, arts and culture, and the use of technology, information and communication (Basuki and Jaelani 2015: 3). Thus, universities should also be able to provide a friendly education for persons with disabilities.

Persons with disabilities who become students are still a minority. This is also stated by Fikriyyah and Fitria (2015: 116) about the existence of people with disabilities as part of the academic community of universities in Indonesia is still a new phenomenon. Similarly, Baihaqi and Sugiarmin (2006: 23) also pointed out that the participation of persons with disabilities in higher education is very low at $0.001 \%$ because the policy towards education for people with disability is still concentrated at the primary and secondary levels. Though people with disabilities have the right to have education including university bench. This is as mentioned in Law No. 4 The year 1997 Article 6 which contains about the rights of PwDs that is 
education on all units, lines, types, and levels of education.

Some colleges have brought their campuses into inclusive campuses by accepting people with disabilities as their students. In Bandung, universities with disability students are Education University of Indonesia, Pasundan University, and Widyatama University. Also, UIN Sunan Kalijaga has 45 students with disabilities (Basuki and Jaelani, 2015: 3). In 2015 at Yogyakarta State University there are three students with disabilities (Rahma, 2015: 1). In Brawijaya University in 2012, there are 15 students with disabilities (Sudjito Soeparman, 2014: 18). This shows the implementation of the right to higher education for persons with disabilities.

Based on data from the Ministry of Social Affairs of the Republic of Indonesia, people with disabilities in nine provinces in Indonesia amounts to 299,203 people. The highest number of persons with disabilities is in West Java province which is $50.90 \%$ (2009). This group of PwDs is entitled to an education as mandated by the 1945 Constitution, Article 31 paragraph 1 which reads "Every citizen is entitled to an education." Therefore, universities must also take a role and participate together with the government and society to build and improve the standard of living persons with disabilities through Tri Dharma Perguruan Tinggi activities.

Persons with disabilities are persons who bear or suffer from an inability. According to Oliver as quoted by Ningsih (2014: 77) disability is a complex phenomenon that reflects the interaction between the characteristics of a person's body and the characteristics of the society in which he lives. It can be interpreted that people who experience or suffer from disorders or problems in their bodily functions will experience the limitations or difficulties to engage or participate in a life situation.

Difabel is an extension of the phrase people with different power, disabled are people who run life activities with physical and or mental conditions which are different from ordinary people. This condition may be innated or presented in adulthood, as a result of illness, malnutrition, accidents, illtreatment, or other causes causing physical and mental disability. The term disabled is officially used to replace the disabling term in 1998. Disabled communities are principally divided into five categories: (1) Blind (limited to the senses of vision), (2) Tuna daksa (limited to limbs), (3) Deaf (limited to the sense of hearing), (4) Speech (limitations in speech), and (5) Mental disabilities (mental limitations) (Ari Zuntriana, 2011: 3).

In Islamic teaching, the condition of disability is contained in the letter At-tin paragraph 4 (Ministry of Religion, 2005) which in the Indonesian language is translated "Sesunggubnya Kami telab menciptakan manusia dalam bentuk yang sebaikbaiknya (Verily We have created human beings in the best possible form)." The verse implies that a state of disability that is physically seen as a deficiency but is a perfect gift. Allah SWT does not regard the condition of disability as a thing to be distinguished or obstacles in the effort toward taqwa. This is as implied in the letter of Al-hujurat verse 13 which reads:

O mankind! We created you from a single pair of a male and a female and made you into nations and tribes that you might get to know one another. Surely the noblest of you in the sight of Allah is he who is the most righteous. Allah is AllKnowledgeable, All-Aware.

Moreover, in a hadith of the Prophet Muhammad (s) narrated by Bukhari Muslim (Akhmad Sholeh, 2015: 310) it is said that "Allah does not see your body, your looks, but God sees your heart." This hadith also illustrates that Islam views human beings more on something that is immaterial. Therefore, humans have the same rights and obligations, and that distinguishes them from the aspect of piety. 
The legal basis for persons with disabilities to obtain the right to education is also contained in the three articles of Law no. 39 of 1999 on Human Rights, which reads "Every citizen is entitled to social security needed for decent living and his personal development as a whole. Every person with disabilities, elderly people, pregnant women, and children shall be entitled to special facilities and privileges. "(Article 41). Article 42 reads "Every elderly citizen, physically disabled or mentally disabled shall have the right to receive care, education and training, and special assistance or state expenses, to ensure a decent living according to the dignity of humanity." Also, in Article 54, "Every child with a physical or mental disability is entitled to special care, education and training, and assistance at the expense of the state, to ensure a decent living in accordance with the dignity of humanity, to increase the confidence and ability to participate in the life of the community, Nation, and state.

There is more than 90 percent of children with disabilities not attending school especially in developing countries. This is the promotion of The Rights of Children with Disabilities by UNICEF cited Ningsih (2014: 75). Sudjito Soeparman points out the academic factors that affect the success of the study of PwDs (2014). Sudjito Soeparman (2014: 17) states that the academic factors that influence the success of the study of PwDs are campus attendance just for college because they feel that some friends are less friendly to disabilities, difficult transportation, and less supportive supporters whereas group learning is considered more effective.

In Indonesia, not many universities are willing to accept the presence of a disability and provide adequate policies and services. But today, some universities are starting to organize inclusive education. Inclusion education is a system or learning environment that provides education for normal children and children with special needs in one environment without distinguishing the background of children (Ro'fah and Muhrisun, 2010: 4). The paradigm of inclusive education is seen as the most friendly paradigm and it is possible for persons with disabilities to get a decent education service, even up to university.

This paper will be discussed the implementation of the paradigm of inclusive education in higher education by the Minister of Education and Culture No. 26 of 2014. As for some things reviewed by the candy, namely: 1) the provision of equal opportunity to register; 2) freedom of choice of study program; 3) providing services as needed.

\section{DISCUSSIONS}

One of the goals of the state as mentioned in the Preamble to the 1945 Constitution of the fourth paragraph is to educate the life of the nation. Education should, therefore, be accessible to all levels of society including persons with disabilities.

Persons with disabilities are part of citizens entitled to an education. This is by the 1945 Constitution Article 31 paragraph 1. Education as a constitutional right is then constructed also as part of Human Rights, through the provision of Article 28C, paragraph (1).

However, for people with disability to continue education until college level is not an easy matter. This is also stated by Ro'fah, et al. (2011). For disabled or disabled persons the level of the university is the most difficult. This is due to several factors including. There are not yet many inclusive and accessible disability campuses (curriculum, instructional media, campus services), strong assumptions that higher education is not for disabled, low quality of disabled education, lecturers who have not understood the teaching and learning process inclusion classes, poor accessibility of buildings, general students do not understand well how to interact with students with disabilities, and discriminatory practices. Also, the lack of literature and 
teaching materials in the form of Braille that can be accessed for the visually impaired, instructors for the deaf add to the long list of factors that make it difficult for people with disabilities for college.

Disability mainstreaming issues in educational activities at universities can be undertaken by implementing the inclusive education paradigm in higher education that is the Minister of Education and Culture No. 26 of 2014. First, equal opportunity to register. Second, the freedom to choose a course/department. Third, the provision of services as needed.

First, giving equal opportunity to register. One of the benchmarks of the quality of students and graduates is how colleges should treat and provide services to students. This can be started since universities have and implement policies on recruitment and selection new students. Colleges must provide an opportunity for every human being to develop its potential as the ideal purpose of education. This shows that persons with disabilities are one part of the selection election. Persons with disabilities who are eligible to continue their education to a higher education level should not be restricted from access. They have the opportunity to enroll and follow the selection process of new admissions.

Providing opportunities for persons with disabilities and their relationship with the efforts of universities to obtain qualified students may be conducted with or through specific recruitment systems and programs. Colleges can conduct the process of conducting pre-university programs, for example by working with an Extraordinary School or an inclusive school in preparing prospective students and then carrying out pre-university training. This is one form of support for new admissions systems to ensure quality, equity, and accessibility effectively.

Second, the freedom to choose a course/department. In practice there may be doubts about PwDs to take a particular course of study, for example, a course that requires no color blindness means that it can not accept a blind student. Such a policy may or may not be renewed by considering other terms. This is sometimes based on the view of disability that they have no ability. However, in reality, some persons with disabilities can boost their potential in areas that others can be considered impossible such as Ludwig van Beethoven who continues to create music even though he is deaf.

The condition of persons with disabilities who may be physically different may not affect the college to cancel or annul to accept it as a student if the reason is not or not related to the requirements to gain knowledge in higher education.

Persons with disabilities need not be limited to choosing courses/majors in higher education. The university should establish itself to be an inclusive educational institution so as to provide flexibility for PwDs to choose the courses/majors they are interested in. Meanwhile, people with disabilities will measure their abilities and conditions (self-esteem). So, not a college education that limits/directs.

Students are internal stakeholder groups that must get the benefit, and at the same time as actors, the process of forming added value in the organization of academic activities/quality programs in college. So students who come from persons with disabilities are learners who need holistic self-development that includes the physical, mental, and personality elements as a qualified human resource in the future. Therefore, in addition to academic services, students need to gain interest and talent development services in the areas of spiritual, cultural, sports, social sensitivity, environmental preservation, and other creativity fields so that students can have professional values, flexible, creative and innovative in preparing to enter the world of profession and or the world of work.

Third, the provision of services as needed. All areas of life accessible to the students of nonvisibility should be 
accessible to students with disabilities. This relates to considerations related to the support and assistance needed for PwDs.

All services related to student interests need to be organized and conditioned also to provide the best service for students with disabilities. In technical service circles often refer to the term after service. Some inputs to consider are (a) creating physical accessibility both in buildings and outside buildings, (b) creating non-physical accessibility, e.g., curricula adapted to disability student conditions, providing accessible IT services, providing assistance, receiving lectures, etc.

The creation of physical accessibility in universities can be done by modifying or adjusting public facilities for persons with disabilities. The principle of accessibility includes three things: the principle of convenience, security, and convenience (Law No. 28 of 2002 Article 27 paragraph 2). Based on Law No. 28 of 2002 about buildings, paragraph 27 paragraph 2, the ease of connections to, from and within the building as referred to in paragraph (1) includes the availability of facilities and accessibility that is easy, safe and comfortable including for people with disabilities and Elderly. The preceding is reaffirmed in article 31 which in essence means that all buildings including the provision of accessibility facilities and other facilities in buildings and environments must accommodate the needs of persons with disabilities.

The management of university facilities and infrastructure includes planning, procurement, use, maintenance, updating, inventory, and asset deletion is well done, so as to effectively support the activities of academic administration in universities. Ownership and accessibility of facilities and infrastructure are essential to ensure the quality of academic implementation sustainably. Also, a good information system supports the implementation of college tri dharma.

It also needs to create non-physical accessibility, such as student services, and the development of interests and talents. Colleges can build relationships with students and stakeholders and determine key factors that lead to satisfaction, student existence, service improvement and educational programs, and college sustainability.

Such management deals with human resources. Human resources consist of lecturers and supporting staff who must have adequate and relevant competencies in sufficient quantities. Lecturers, as the main human resources in the process of creating a value-added quality of the students, need to be initiated to be able to develop themselves so that it can run an inclusive education.

In the academic activities, the development and stipulation of the curriculum of the study program, the university should be able to function as an enabler for the activities of the study program. The university is obliged to facilitate the study program's efforts to improve social, scientific and personal relevance, through periodic updating of the curriculum with stakeholders. This can be utilized to build a curriculum that has accessibility value and can contribute to determining the suitability of the students' success either students with a disability or not with the competence required by the graduate and the development of science and technology.

Another thing to note is the research and community service that is organized for and related to the development of the quality of higher education. In her writings, Ningsih (2014: 89) offers a variety of themes that can be used for research and community service to the mainstreaming of the disability issue. These themes can also be used in a college setting. These themes can be offered to lecturers and students and published in the form of paper, theses, dissertations, articles, freelance writings, etc., for example, disability and Islam, the important role of inclusive education, learning for persons with disabilities in universities, disability, and gender, the development of conventions and the Laws of PwDs, the effort to break the negative stigma of disability, the disability friendly interpretation. 
Ningsih (2014: 90) has a theme of devotion, for example, to assist the community with disabilities, advocate mosque accessibility, build campus network, community, and community with disabilities, offer discourse-friendly Islamic discourse, build cooperation with various stakeholders about disability issues, engage in the development of disability policies, conduct pre, post, and campus programs for disabled students, advocate for employment for persons with disabilities, initiate disability service centers at universities. These themes can be adapted by universities to mainstream disability issues in universities.

\section{CONCLUSION}

The understanding of a disabilityfriendly education is not just an offer. This is one of the obligations that must be implemented in relation with human beings and with the Constitution. Understanding and building services for persons with disabilities need to be done. There are three things that can be done by universities as a form of implementing the paradigm of inclusive education in higher education as adjusted by the Minister of Education and Culture No. 26 of 2014 which provides equal opportunity to register, giving freedom to choose courses/majors, and provide services in accordance with needs both physical and non-physical. Another thing to note is the research and community service that is organized for and related to the development of the quality of higher education.

Views of persons with disabilities should also be improved. Limitations that exist in themselves are not an option but inevitably must be accepted and lived. Anyone has the potential to turn into a person with a disability. Therefore, services and the fulfillment of the rights of persons with disabilities need to be guaranteed, including in education.

\section{REFERENCES}

Baihaqi, MIF dan M. Sugiarmin. (2006). Memahami dan Membantu Anak. ADHD. Bandung: Refika Aditama.

Basuki, Udiyo dan Abdul Qodir Jaelani. (2015). Kajian atas pelaksanaan pemenuhan hak pendidikan tinggi bagi penyandang difabilitas di UIN Sunan Kalijaga melalui pengesahan Convention on the Rights of Person with Disabilities sebagai upaya perlindungan hak asasi manusia dalam negara hukum Indonesia, Panggung Hukum Jurnal Perbimpunan Mahasiswa Hukum Indonesia Cabang Daerah Istimewa Yogyakarta, Volume 1, No. 2 , hlmn 1-34.

Fikriyyah, Wieda Rifatif dan Maya Fitria (2015). Adversity quotient mahasiswa tunanetra, Jurnal Psikologi Tabularasa, Volume 10, No. 1, hlmn 115-128.

Ningsih, Ekawati Rahayu Ningsih. (2014). Mainstreaming isu disabilitas di masyarakat dalam kegiatan penelitian maupun pengabdian pada masyarakat di STAIN Kudus, Jurnal Penelitian, Volume 8 No. 1, hlm 7193.

Rahma, Riska Nurwijayanti. (2015). Kesejahteraan Psikologis Penyandang Tunanetra (Studi pada Mahasiswa Tunanetra Fakultas Ilmu Pendidikan Universitas Negeri Yogyakarta). Skripsi tidak dipublikasikan. Yogyakarta: Universitas Negeri Yogyakarta.

Ro'fah, A., dan Muhrisun, A. (2010). Inklusi pada Pendidikan Tinggi: Best Parctice Pembelajaran dan Pelayanan Adaptif bagi Mahasiswa Difabel Netra. Yogyakarta: PSLD UIN Sunan Kalijaga.

Ro'fah, A., Supartini., Jahidin, A., Rozaki, A., Mulayani, S., dan Aslamah, S. (2011). Menuju Yogyakarta yang Inklusif. Kajian Akademik Raperda Penyandang Disabilitas Propinsi DIY. Yogyakarta: 
Dinas Sosial Provinsi DIY dan PSLD UIN Sunan Kalijaga.

Sholeh, Akhmad. (2015). Islam dan Penyandang Disabilitas: Telaah Hak Aksesibilitas Penyandang Disabilitas dalam Sistem Pendidikan di Indonesia, Palastren, Vol.8, No. 2, hlmn 293-319.

Soeparman, Sudjito. (2014). Faktor-faktor yang mempengaruhi keberhasilan studi mahasiswa penyandang disabilitas, Indonesian Journal of Disability Studies, Volume 1, Issue 1, hlmn. 12-19.

Undang-Undang Dasar Tahun 1945 Pasal 31 Tentang Pendidikan. Jakarta: Republik Indonesia.

Undang-Undang Nomor 39 Tahun 1999 Tentang Hak Asasi Manusia. Jakarta: Departemen Sosial Republik Indonesia.

Undang-Undang Nomor 4 Tahun 1997 Tentang Penyandang Cacat. Jakarta: Departemen Sosial Republik Indonesia.

Zuntriana, Ari. (2011). Hak atas informasi bagi difabel, Jurnal Pustakaloka STAIN Ponorogo, Vol. 1, No. 2, hlmn 1-11. 